\title{
Characterization of the Kilham Rat Virus
}

\author{
LOIS ANN SALZMAN AND LEE ANN JORI \\ Laboratory of Biology of Viruses, National Institute of Allergy and Infectious Diseases, National Institutes of \\ Health, Bethesda, Maryland 20014
}

Received for publication 21 October 1969

\begin{abstract}
Kilham rat virus (KRV) was found to grow in a rat nephroma cell line and to form plaques on secondary rat embryo monolayers. The virus was purified by enzymatic treatment and isopycnic cesium chloride sedimentation. KRV bands at a density of $1.41 \mathrm{~g} / \mathrm{cm}^{3}$ in cesium chloride. It contains about $26.5 \%$ deoxyribonucleic acid (DNA). The sedimentation coefficient $S_{20 \text {,w }}$ in sucrose gradients was 122 corresponding to a molecular weight of $6.6 \times 10^{6}$ daltons. The reaction of formaldehyde with the KRV virion suggests that the DNA in situ is single-stranded. DNA extracted from KRV had a buoyant density of $1.715 \mathrm{~g} / \mathrm{cm}^{3}$ in cesium chloride. The $S_{20 \text {,w }}$ was determined in sucrose gradients to be 16 , and the molecular weight was calculated to be approximately $1.7 \times 10^{6}$ daltons. The base composition of the DNA is $26.7 \%$ adenine, $30.8 \%$ thymine, $20.0 \%$ guanine, and $22.5 \%$ cytosine. On the basis of its noncomplementary nucleotide ratio, melting curve, and the reaction with formaldehyde, the DNA of KRV is believed to be single-stranded.
\end{abstract}

Kilham rat virus (KRV) is one of a group of small $(15$ to $30 \mathrm{~nm})$ DNA containing animal viruses called the picodnaviruses (19). Originally isolated from a rat sarcoma (11), KRV was shown to be widely spread as a latent infection of normal rats (12). The virus can produce an acute fatal illness or specific deformities of growth and development when injected into newborn hamsters $(2,16) . K R V$ produces intranuclear inclusion bodies in epithelial connective tissue and fibroblastic rat embryo cells. Rabson et al. (22) found that these intranuclear inclusions were feulgen positive, suggesting the deoxyribonucleic acid (DNA) nature of the virus. Jamison and Mayor (9), using acridine orange staining techniques, and Robinson and Hetrick (23), utilizing a variety of physical and chemical techniques, concluded that the DNA of rat virus was single-stranded. On the other hand, May and his co-workers (18) concluded on the basis of acridine orange staining, melting point, and effect of formaldehyde on the viral DNA that KRV contains double-stranded DNA. Our studies on the KRV-DNA, including the determination of the nucleotide ratio of the KRV-DNA, support its single-stranded nature.

\section{MATERIALS AND METHODS}

Virus and cell line. KRV strain 308 was originally obtained from L. Kilham. It was a gift from D. Axelrod. The virus was grown in a rat nephroma cell line obtained from Virginia Babcock (1). The cells were grown in Eagles basal medium containing $4 \%$ glutamine and supplemented with $10 \%$ fetal bovine serum.

Virus purification. Monolayer cultures of rat nephroma in 32-oz $(960 \mathrm{ml})$ prescription bottles containing about $30 \times 10^{6}$ cells were infected with $10^{6}$ to $2 \times 10^{6}$ plaque-forming units (PFU) of KRV. After an adsorption period of $2 \mathrm{hr}$, at $37 \mathrm{C}, 40 \mathrm{ml}$ of fresh medium containing $5 \%$ fetal bovine serum was added. Five days after infection, the cells were removed from the bottles with $5 \mathrm{ml}$ of $0.25 \%$ trypsin, washed, and resuspended in Eagle's basal medium. The cells were then frozen and thawed three times and treated with $1 \%$ receptor-destroying enzyme (Microbiological Associates, Inc., Bethesda, Md.) for $16 \mathrm{hr}$ at $37 \mathrm{C}$. The suspension was centrifuged at $1,000 \times g$ and $23 \mathrm{C}$ for $5 \mathrm{~min}$, and the supernatant fraction was tested for hemagglutination (HA) activity and ability to form plaques on secondary rat embryo monolayers. The supernatant fraction was then centrifuged in a cesiumchloride gradient (average density $1.41 \mathrm{~g} / \mathrm{ml}$ ) in a Spinco model L centrifuge at $35,000 \mathrm{rev} / \mathrm{min}$ and $5 \mathrm{C}$ for $24 \mathrm{hr}$ in a type 40 rotor. The peaks of HA activity were assayed for plaque-forming ability. The HA activity peak at a density of 1.40 to 1.41 which contained most of the infective virus particles was recentrifuged as above. The single peak of HA activity obtained was used for characterization of the virus and extraction of the DNA.

Preparation of radioactive KRV. Rat nephroma cells were infected as described above. After the 2-hr adsorption period, $10 \mathrm{ml}$ of medium was added containing $40 \mu \mathrm{c}$ of ${ }^{3} \mathrm{H}$-thymidine (specific activity, $20 \mathrm{c}$ per mmole per mg; New England Nuclear Corp., Boston, Mass.) or $4 \mu \mathrm{c}$ of ${ }^{14} \mathrm{C}$-thymidine (specific activity, 60 mc per mmole per mg; New England Nuclear Corp.) per $\mathrm{ml}$. After incubation at $37 \mathrm{C}$ for an additional 4 $\mathrm{hr}$, another $30 \mathrm{ml}$ of medium was added to the culture. The cells were harvested, and the virus was purified as described above.

Assay for HA and hemagglutination inhibition (HI). 
HA was measured using twofold dilutions of virus in $0.2-\mathrm{ml}$ volumes of phosphate-buffered saline $(\mathrm{pH}$ 7.4). This solution was mixed with an equal volume of $2 \%$ guinea pig red blood cell suspension. The point of partial agglutination was read after incubation for 1 to $2 \mathrm{hr}$ at room temperature. The hemagglutination units (HAU) are defined as the reciprocal of the dilution causing partial agglutination.

Antiserum against KRV was purchased from $\mathrm{Mi}$ crobiological Associates, Bethesda, Md. It had a HI titer of 1:320. An additional sample of antiserum with a HI titer of $1: 10,240$ was a gift from M. D. Hoggan. Inhibition of virus hemagglutination was determined by incubating twofold dilutions of antiserum with $32 \mathrm{HAU}$ of virus in a total volume of 0.2 $\mathrm{ml}$ at room temperature for $60 \mathrm{~min}$. A $0.2-\mathrm{ml}$ sample of guinea pig red blood cells $(2 \%)$ was then added. The mixture was then incubated at room temperature for an additional $2 \mathrm{hr}$. The titration end point was the lowest serum dilution showing HA.

Plaque formation. Cells $\left(5 \times 10^{6}\right)$ of secondary cultures of rat embryo cells in Eagle's basal media containing $10 \%$ calf serum and $4 \%$ glutamine were seeded in tissue culture dishes ( 60 by $15 \mathrm{~mm}$; Falcon Plastics, Los Angeles, Calif.). When the cell cultures were confluent ( 24 to $48 \mathrm{hr}$ after seeding), they were infected with $0.2 \mathrm{ml}$ of virus dilution. Virus adsorption was continued for $2 \mathrm{hr}$ at $37 \mathrm{C}$ in an atmosphere of $3 \%$ carbon dioxide. Medium ( $5 \mathrm{ml}$ ) containing $0.9 \%$ agar was then added to each dish. The cultures were incubated for 5 days at $37 \mathrm{C}$ in carbon dioxide atmosphere. A second 5-ml media-agar layer (as above, but also containing a $1: 10,000$ dilution of neutral red) was then added. The plates were reincubated, and the plaques were visible in 12 to $24 \mathrm{hr}$. The plaques were about 2 $\mathrm{mm}$ in diameter and increased in size with a longer time of incubation.

Chemical and radioactive analysis of KRV. Protein determinations were made by the method of Lowry et al. (14) with bovine serum albumin as the standard. DNA estimations were made by using Burton's modification of the diphenylamine reaction (5); salmon sperm DNA was used as a standard.

Electron microscopy of KRV. Virus particles purified in a cesium chloride density gradient were examined in negatively stained preparations by using uranyl acetate ( $1 \%$ in water, $p \mathrm{H} 5$ to 7$)$. Electron micrographs were taken in a Siemens Elmiskop 1A, at an instrument magnification of 145,000 to 200,000 .

Extraction of the DNA. The DNA was extracted from the purified virus preparation in $0.02 \mathrm{M}$ phos-

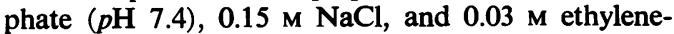
diaminetetraacetate (EDTA) by the addition of sodium lauryl sulfate to a final concentration of $2 \%$. The suspension was heated at $50 \mathrm{C}$ for $20 \mathrm{~min}$, chilled, and $1 \mathrm{~g} \mathrm{CsCl}_{2}$ per $\mathrm{ml}$ of solution was added. After centrifugation at 7,000 $\times \mathrm{g}$ and $4 \mathrm{C}$ for $15 \mathrm{~min}$ in a Sorvall RC-2B centrifuge, the clear DNA-CsCl solution was easily separated from the sodium lauryl sulfate pellicle. The DNA was then centrifuged in a SW-50 rotor in a Spinco model L2 centrifuge at $40,000 \mathrm{rev} / \mathrm{min}(20 \mathrm{C}$ ) for $48 \mathrm{hr}$ in a cesium chloride gradient of average density 1.71 . Fifty $1-\mathrm{ml}$ fractions were collected. Radioactive viral DNA was located in the gradient by counting a sample of each fraction in Triton X-100 scintillation fluid (20).

Velocity sedimentation. Purified KRV (0.15 ml) plus $0.01 \mathrm{ml}$ of simian virus 40 (SV40; gift of C. Patch) or polyoma virus (gift of $\mathbf{N}$. Crane and $\mathbf{P}$. Qasba) were layered on $11.0 \mathrm{ml}$ of a linear sucrose gradient and centrifuged for $55 \mathrm{~min}$ at $40,000 \mathrm{rev} / \mathrm{min}$ and $20 \mathrm{C}$ by using the type $41 \mathrm{~T}$ rotor in a Spinco L2 ultracentrifuge. A gradient of 5 to $25 \%$ sucrose in $0.01 \mathrm{M}$ tris(hydroxymethyl)aminomethane (Tris) 0.001 M EDTA ( $p \mathrm{H}$ 7.4) was used. After centrifugation, $0.12-\mathrm{ml}$ fractions were collected from the gradient through a hole punctured in the bottom of the tube. Drops were collected directly into a counting vial. Water $(1 \mathrm{ml})$ plus a Triton X-100 scintillation fluid $(10 \mathrm{ml})$ was then added to each vial.

Purified KRV-DNA was also sedimented with polyoma virus component II. Ethidium bromidepurified DNA component I (gift of E. Sebring) was converted to component II with deoxyribonuclease I (Worthington Biochemical Corp., Freehold, N.J.) as described by Vinograd et al. (29). The conditions used were those described for the conversion of at least $63 \%$ of component I to component II by one singlestranded break in the double-stranded circular component I. A mixture $(0.15 \mathrm{ml})$ of polyoma virus DNA component II and KRV-DNA, containing a total of less than $0.2 \mu \mathrm{g}$ of DNA, was layered on a 5 to $30 \%$ linear sucrose gradient containing $1.0 \mathrm{M} \mathrm{NaCl}, 0.02 \mathrm{M}$ Tris, $0.2 \mathrm{M} \mathrm{NaOH}$, and $0.001 \mathrm{M}$ EDTA ( $p \mathrm{H} 12.2)$. The $11-\mathrm{ml}$ gradient was centrifuged at $35,000 \mathrm{rev} / \mathrm{min}$ at $20 \mathrm{C}$ for $18 \mathrm{hr}$ in a SW $41 \mathrm{~T}$ rotor in a Spinco L2 centrifuge. Fractions were collected into counting vials and assayed for radioisotope content (as above).

Effect of formaldehyde. KRV and purified DNA extracted from the virus were each suspended in $0.1 \mathrm{M}$ phosphate buffer, $p \mathbf{H}$ 7.5. Neutralized formaldehyde was added to give a final concentration of $1.8 \%$ formaldehyde. The density changes at $260 \mathrm{~nm}$ were followed in a Beckman DU spectrophotometer at $37 \mathrm{C}$ for $20 \mathrm{hr}$. As a control, both native and heatdenatured salmon sperm DNA were incubated with formaldehyde under the same conditions, and the spectral changes at $260 \mathrm{~nm}$ followed.

Thermal denaturation of KRV-DNA. Purified KRVDNA in citrate buffer (SSC, $0.015 \mathrm{M}$ citrate plus 0.15 $\mathrm{M} \mathrm{NaCl}$ ) was placed in a $0.3-\mathrm{ml}$ quartz microcell. The cuvette was sealed to prevent evaporation at high temperatures and placed in a Gilford model 2000 multiplesample absorbance recorder attached to a Beckman DU optical system. The temperature in the cuvette chamber was increased $1 \mathrm{C} / \mathrm{min}$ from 28 to $100 \mathrm{C}$, and the $E_{260}$ (extinction coefficient) was recorded every $20 \mathrm{sec}$. Controls, which were run at the same time as the KRV-DNA, included one cuvette containing mouse embryo DNA in SSC and one containing SSC alone. The absorption at $260 \mathrm{~nm}$ of the cuvette containing the buffer alone was subtracted from the sample readings to correct for thermal expansion.

Base analysis of KRV-DNA. Purified radioactive (32P-labeled) KRV was prepared as described above in virus purification by using, however, a phosphatefree Eagle's medium plus $50 \mu \mathrm{c}$ of carrier-free ${ }^{32} \mathrm{P}$ orthophosphate per ml. Purified KRV-DNA was 
digested to yield deoxyriboside $3^{\prime}$-phosphates as described by Josse et al. (10). Salmon sperm DNA was added as carrier, and digestion was accomplished by using micrococcal nuclease and calf spleen phosphodiesterase. The 3'-deoxyribonucleotides were separated on filter paper by electrophoresis in a Gilson high-voltage electrophorator with pyridine acetate buffer ( $p \mathrm{H} \mathrm{3.5)}$ at 3,000 v for $75 \mathrm{~min}$, and their radioactivities were determined.

Digestion of KRV-DNA to yield 5 '-mononucleotides was accomplished by the procedure of Crawford et al. (7) by using pancreatic deoxyribonuclease and snake venom phosphodiesterase. A nucleotide mixture containing $0.25 \mathrm{mg}$ of each $5^{\prime}$-deoxyribonucleotide was added as carrier before electrophoresis. The nucleotides were separated and their radioactivities were determined as described above.

Density of DNA. Buoyant densities of KRV-DNA were determined in equilibrium density gradients of a $\mathrm{CsCl}$ solution density $1.715 \mathrm{~g} / \mathrm{cm}^{3}(0.001 \mathrm{M}$ EDTA

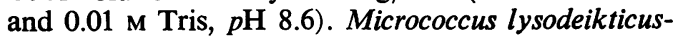
DNA was added as a marker. Centrifugations were performed at $25 \mathrm{C}$ and $44,770 \mathrm{rev} / \mathrm{min}$ in the Spinco model $\mathrm{E}$ ultracentrifuge equipped with ultraviolet absorption optics, and photographic negatives were analyzed with the Spinco Analytrol densitometer.

\section{RESULTS}

Isolation and purification of KRV. KRV replicates in the rat nephroma cell line and causes a marked cytopathogenic effect. The virus remains associated with the cells and is released by freezing and thawing the cells and treating them with receptor-destroying enzyme. Purification of the virus in a cesium chloride gradient yielded three peaks of $\mathrm{HA}$ at densities of $1.41,1.38$, and 1.36
(Fig. 1). Electron micrographs of the material in the three HA peaks were taken. The HA peak at a cesium chloride density of 1.41 contained virus particles 18 to $20 \mathrm{~nm}$ in diameter (Fig. 2). The peak of HA at a cesium chloride density of 1.38 also contained virus particles of 18 to $20 \mathrm{~nm}$, but were penetrated by the negative stain. These particles are considered empty or with a greatly reduced DNA content. The peak of HA material at the top of the cesium chloride gradient was

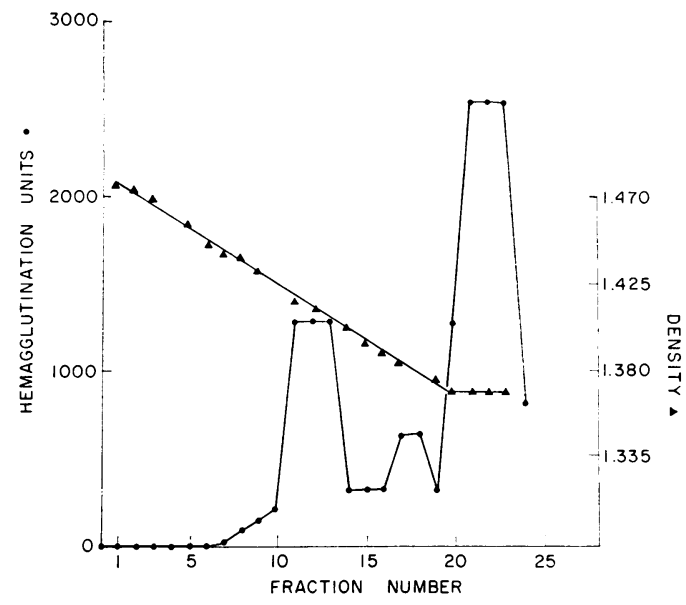

FIG. 1. Isopycnic gradient centrifugation of $K R V o b$ tained from cell lysates. Centrifugation in CsCl (average density, $\left.1.41 \mathrm{~g} / \mathrm{cm}^{3}\right)$ at $80,760 \times \mathrm{g}$ and $5 \mathrm{C}$ for 24 hr. Symbols:, hemagglutination units; $\mathbf{\Delta}$, density of gradient fractions.

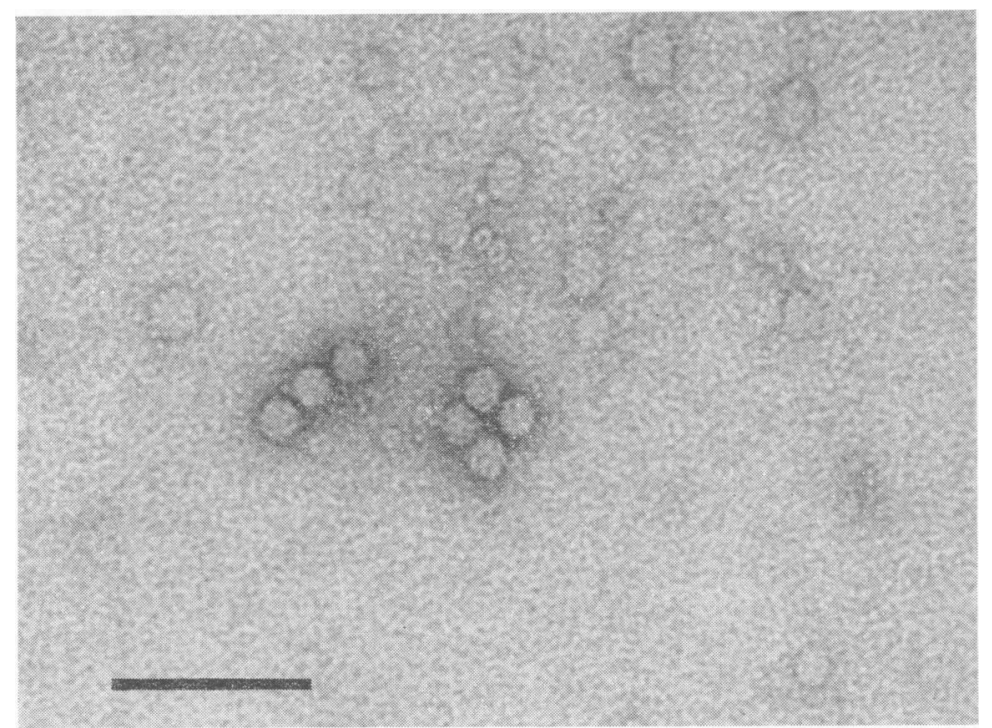

FIG. 2. Electron micrograph of KRV. The virus is stained with $1 \%$ uranyl-acetate, pH 5 to 7 . Micrograph taken by M. D. Hoggan. $\times 200,000$. Marker represents $100 \mathrm{~nm}$. 
found to contain mostly disrupted cellular debris. Few virus particles either intact or empty were seen.

Each sample from the cesium chloride gradient was also tested for its ability to form plaques on rat embryo monolayers. Eighty to ninety per cent of the viral PFU was found associated with the virus particles at a density of 1.41. Another 5 to $10 \%$ of the PFU was associated with HA peak at density 1.38 , and the rest was scattered throughout the gradient.

The viral band at cesium chloride density of 1.40 to 1.41 was reequilibrated in a second cesium chloride gradient. After reequilibration, there was a single peak of virus at a density of 1.41 (Fig. 3). The peak fractions from this gradient were used for all further virus and viral DNA studies.

Immunological characterization of KRV. To determine whether KRV grown in the rat nephroma cell line was altered in its antigenic properties, HI studies were carried out comparing the original stock virus and the virus after growth in the nephroma cell line. Antiserum preparations from two different sources were used in the assays. These studies indicated that the purified KRV retained its original antigenic properties after 20 to 60 passages in the rat nephroma cell line. The antiserum titer was the same for the original stock virus and for the virus purified after passage in the nephroma cell line.

Properties of KRV. Chemical analysis of the virus was carried out by using the Burton modification of the diphenylamine assay for DNA (5) and the Lowry protein assay (14). If the complete virion contains only DNA and protein, it is composed of approximately $25.6 \%$ DNA.

Since the secondary structure of KRV-DNA

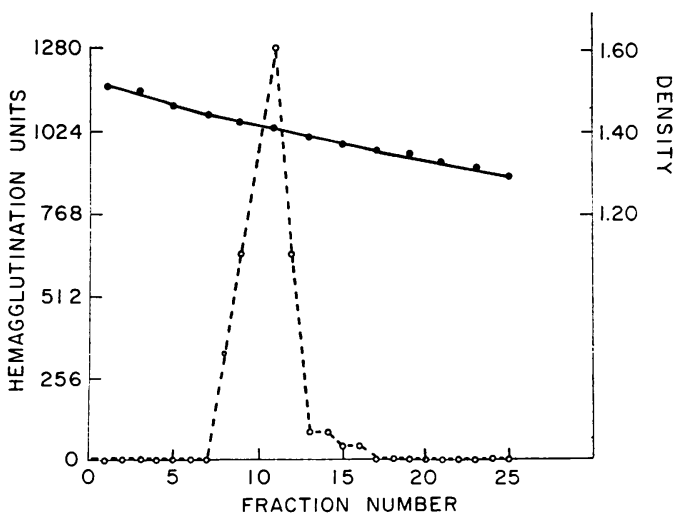

Fig. 3. Recentrifugation in $\mathrm{CsCl}$ of the peak hemagglutination fractions (density 1.40 to 1.41) seen in Fig. 1 . Conditions used in centrifugation are given in the legend to Fig. 1. Symbols: O, hemagglutination units; 0 , density of gradient fractions. was reported by some workers to be doublestranded (18) and by others to be single-stranded $(9,23)$, we wished to investigate the configuration of the viral DNA in the intact virion. Sinsheimer (25) showed that formaldehyde could react with DNA bases in the intact $\phi$ X174 virion. One of the effects of formaldehyde on single-stranded DNA is to increase its absorption at $260 \mathrm{~nm}$ by reacting with available free amino groups. Polymerized double-stranded DNA should have no free amino groups available for reaction with formaldehyde because of the hydrogen bonding between base pairs. Intact KRV was exposed to formaldehyde over a $20-\mathrm{hr}$ period, and the change in absorption at $260 \mathrm{~nm}$ was followed. Denatured single-stranded and native double-stranded salmon sperm DNA were used as controls. The denatured DNA control showed an increase in absorption at $260 \mathrm{~nm}$ of approximately $18 \%$ (Fig. 4). The absorption of the native DNA control increased less than $2 \%$ during the incubation period. Intact KRV in the presence of formaldehyde showed an increase in optical density at $\mathbf{2 6 0}$ $\mathrm{nm}$ of 13 to $16 \%$. The protein coat of $\mathrm{KRV}$ is therefore penetrated by formaldehyde, and the nucleic acid bases are able to react with the formaldehyde. Robinson and Hetrick (23) reported an increase of 6 to $12 \%$ in $E_{260}$ with KRV. Similarly, the single-stranded DNA virus, MVM shows an increase in $E_{260}$ of $18 \%$ (6) and $\phi X 174$ of $21 \%$ (25) after reaction with formaldehyde.

The relative sedimentation coefficient of KRV was determined for the purpose of comparison with other viruses. In these experiments, KRV

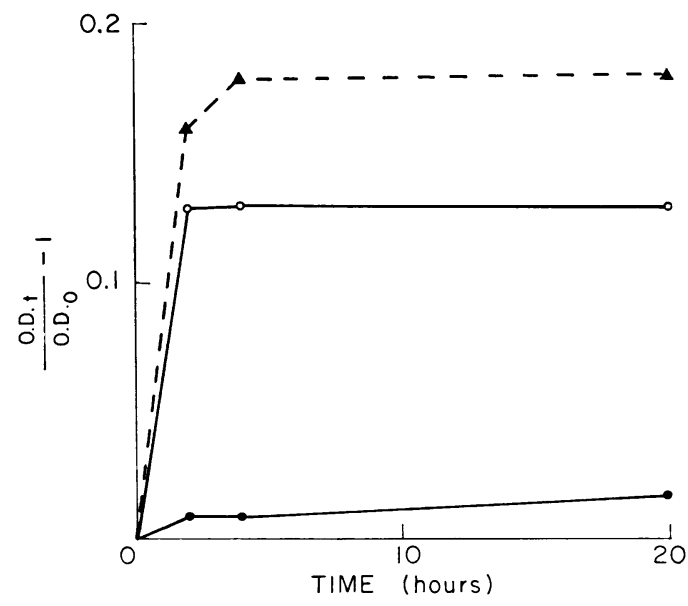

Fig. 4. The effect of formaldehyde $(1.8 \%, \mathrm{pH} 7.5)$ at 37 on: (A) denatured salmon sperm DNA, (O) native salmon sperm $D N A$, and (O) $K R V$. Optical density followed at $260 \mathrm{~nm}$. OD, optical density at zero time; $O D_{t}$, optical density at 2,4 , or $20 \mathrm{hr}$ after addition of formaldehyde. 
was cosedimented in a sucrose gradient with either SV40 or polyoma virus containing an alternate radiolabel. After collecting fractions from the gradient, the distance that each molecule migrated could be determined. The $S_{20}$, w of SV40 virus was reported as 219 (13) and for polyoma virus the $S_{20, \text { w }}$ is $242(30)$. Polyoma virus and KRV sedimented in separate homogeneous bands, giving sharp distinct peaks of radioactivity (Fig. 5). A similar profile was obtained after sedimentation of SV40 and KRV. The $S_{20}$, w calculated for KRV was 121, using polyoma virus as a marker and 124 with the SV40 marker. Under the conditions used here, therefore, KRV had a relative $S_{20}$, w of $122.5 \pm 1.5$.

Properties of KRV-nucleic acid. When DNA was extracted from KRV labeled with radioactive ${ }^{3} \mathrm{H}$ - or ${ }^{14} \mathrm{C}$-thymidine, 40 to $50 \%$ of the radio isotope was recovered in the DNA fraction. If the radioactive DNA was centrifuged to equilibrium in a cesium chloride gradient, over $90 \%$ of the

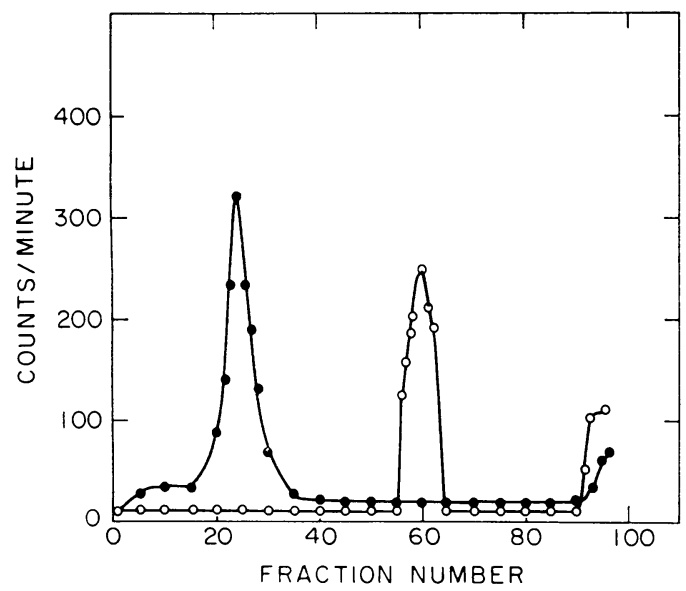

FIG. 5. Sedimentation of $K R V$ and polyoma virus. The viruses were centrifuged in a 5 to $25 \%$ sucrose gradient ( $p H 7.4$ ) for $55 \mathrm{~min}$ at $20 \mathrm{C}$ in a SW $41 \mathrm{~T}$ rotor at 40,000 rev min. Sedimentation is from right to left. Symbols: 0 , polyoma virus; $\bigcirc, K R V$. radioisotope was found in the fraction with a density of 1.71 to $1.72 \mathrm{~g} / \mathrm{cm}^{3}$. This is in agreement with the density of $1.72 \mathrm{~g} / \mathrm{cm}^{3}$ recently reported (23). Isopycnic centrifugation in the Beckman model $E$ analytical centrifuge was also carried out to determine the density of KRVDNA. M. lysodeikticus DNA with a density of $1.732 \mathrm{~g} / \mathrm{cm}^{3}$ was used as a marker. Both DNA preparations were homogeneous and equilibrated as sharp distinct bands. The density of KRVDNA was calculated to be $1.715 \mathrm{~g} / \mathrm{cm}^{3}(15)$. This density could correspond either to single-stranded DNA containing $41 \%$ guanine plus cytosine (GC) or to double-stranded DNA containing $56 \%$ GC (24).

The base composition of KRV-DNA was then chemically determined. Table 1 shows the distribution of radioactivity in the four deoxynucleotides. The amount of radioactivity recovered in each nucleotide was taken to represent the relative amount of the corresponding nucleotide in the DNA. KRV-DNA was found to contain $26.7 \%$ adenine, $30.8 \%$ thymine, $20.0 \%$ guanine, and $22.5 \%$ cytosine. There was no significant difference between the base compositions calculated from the $3^{\prime}$ and $5^{\prime}$-hydrolysates. The recovery of the radiosotope applied to the electrophoresis paper varied in these three experiments from 91 to $95 \%$. The DNA did not contain equimolar amounts of adenine and thymine or of GC. Thus, the DNA is probably single-stranded in nature.

Further indications of the single-stranded nature of the KRV-DNA came from thermal denaturation experiments and reaction of the extracted DNA with formaldehyde. When KRVDNA was subjected to an increase in temperature from 28 to $104 \mathrm{C}$, no change in $\mathrm{OD}_{260}$ was observed from 28 to $48 \mathrm{C}$. A gradual increase in optical density was observed from 50 to $100 \mathrm{C}$ (Fig. 6). The increase at $100 \mathrm{C}$ was $12.8 \%$. When the DNA was quickly cooled in ice, no residual hyperchromicity remained. As a control, mouse

TABLE 1. Base composition of Kilham rat virus $D N A$

\begin{tabular}{|c|c|c|c|c|c|c|c|c|c|}
\hline \multirow{2}{*}{$\begin{array}{l}\text { Experiment } \\
\text { no. }\end{array}$} & \multirow{2}{*}{$\begin{array}{l}\text { Type of } \\
\text { hydrolysis }\end{array}$} & \multicolumn{2}{|c|}{ Adenine } & \multicolumn{2}{|c|}{ Thymine } & \multicolumn{2}{|c|}{ Guanine } & \multicolumn{2}{|c|}{ Cytosine } \\
\hline & & $\begin{array}{c}\text { Counts/ } \\
\text { min }\end{array}$ & $\begin{array}{c}\text { Total } \\
\text { counts } / \text { min }\end{array}$ & $\underset{\text { min }}{\text { Counts/ }}$ & $\begin{array}{c}\text { Total } \\
\text { courts } / \text { min }\end{array}$ & $\underset{\text { min }}{\text { Counts/ }}$ & $\begin{array}{c}\text { Total } \\
\text { counts/min }\end{array}$ & Counts/min & $\begin{array}{c}\text { Total } \\
\text { counts } / \mathrm{min}\end{array}$ \\
\hline & & & $\%$ & & $\%$ & & $\%$ & & $\%$ \\
\hline 1 & $3^{\prime}$ & 827 & 27.1 & 916 & 30.1 & 594 & 19.5 & 709 & 23.3 \\
\hline 2 & & 657 & 26.8 & 745 & 30.4 & 490 & 20.0 & 558 & 22.8 \\
\hline 3 & $5^{\prime}$ & 627 & 26.3 & 760 & 31.9 & 489 & 20.5 & 508 & 21.3 \\
\hline Avg & & & 26.7 & & 30.8 & & 20.0 & & 22.5 \\
\hline
\end{tabular}




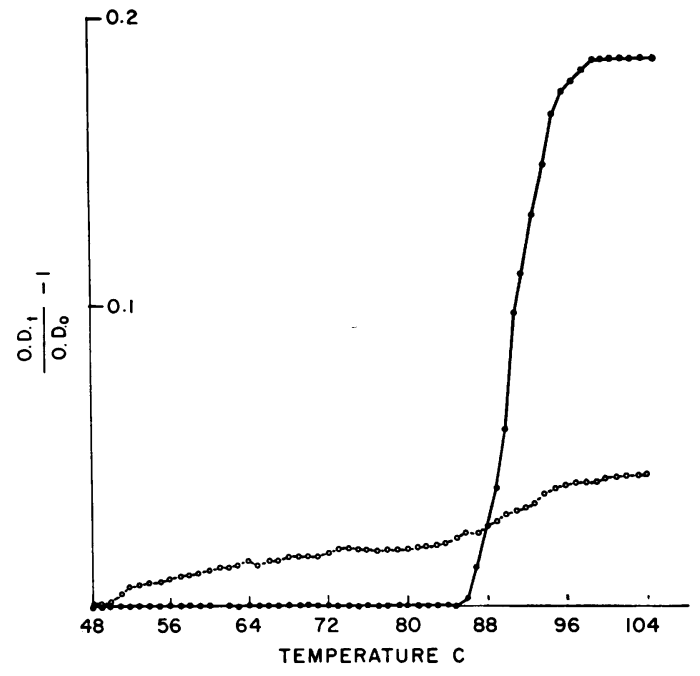

FIG. 6. Thermal denaturation of $K R V-D N A$ and mouse spleen $D N A$ in $0.015 \mathrm{M}$ citrate plus $0.15 \mathrm{M}$ NaCl. Symbols: O, KRV-DNA; , mouse spleen DNA. $O D_{0}$ indicates optical density at $260 \mathrm{~nm}$ at each temperature indicated.

spleen DNA, a gift from Dr. Martin, was run at the same time and under the same conditions as KRV-DNA. The mouse DNA exhibited the sharp melting temperature characteristic of doublestranded DNA. The $T_{m}$ at $86.5 \mathrm{C}$ is in agreement with that reported by Marmur and Doty (17). The increase in optical density was $84 \%$. When the DNA from the mouse spleen was cooled quickly in ice, approximately $30 \%$ of the hyperchromicity was retained. The lack of a sharp $T_{m}$ and low residual hyperchromicity with KRV-DNA is a further indication of its single-stranded nature.

The extracted KRV-DNA was also found to react with formaldehyde. Native and heat-denatured salmon sperm DNA were used as controls. The KRV-DNA and the heat-denatured salmon sperm DNA both showed an increase in absorption at $260 \mathrm{~nm}$ of approximately $18 \%$. An increase in $E_{260}$ of $16.4 \%$ was reported (23). Native double-stranded DNA showed an increase in $E_{260}$ of about $2 \%$.

Sedimentation coefficient and molecular weight determination of KRV-DNA. Accurate measurements of sedimentation rates can be obtained by zonal centrifugation in a sucrose gradient of a mixture of two labeled DNA species at low concentration. The ratio of the sedimentation distances in the gradient is almost directly proportional to the sedimentation coefficient and is also related to the molecular weights of the DNA (4, 27). DNA sedimentation was studied immediately after its release from the intact virus par- ticle. KRV and polyoma virus containing DNA with alternate radioisotope labels were mixed, disrupted in $0.2 \mathrm{~N} \mathrm{NaOH}$, and centrifuged in a sucrose gradient $(p H$ 12.2). Polyoma virus DNA component I, under the conditions employed, has an $S_{20 \text {, w }} 53$ and would sediment to the bottom of the gradient. Polyoma virus DNA component II with an $S_{20 \text {, w }}$ of 16 would sediment to about the center of the gradient (29). Less than 0.2 $\mu \mathrm{g}$ of viral DNA was added to each gradient. KRV-DNA cosediments with the polyoma virus DNA-component II (Fig. 7). The two peaks of radioisotopes are superimposed. Thus KRV-DNA appears to have a sedimentation rate identical to or close to that of single-stranded polyoma virus DNA. Purified polyoma virus component II was also cosedimented with purified KRV-DNA under the same conditions as above. The sedimentation rates of the two viral DNA species are again very similar (Fig. 8). KRV appears to migrate one fraction faster than the single-stranded polyoma DNA. The distance sedimented in the sucrose gradient of each viral DNA was shown to be equal to its sedimentation coefficient (3, 4). From the two experiments reported, the sedimentation coefficient of KRV-DNA was calculated to be $16.1 \pm 0.1$. For linear, alkalidenatured DNA, Studier reports the following relationship: $S_{20, w}=0.528 \mathrm{M}^{0.400}$ when $\mathrm{M}=$ molecular weight (27). By using the above $S_{20 \text {, w }}$ value, the molecular weight of KRV-DNA can be calculated to be $1.7 \pm 0.1 \times 10^{6}$ daltons. When $\mathrm{KRV}$ is $25.6 \%$ DNA, the molecular weight of the intact virus particle would be approximately $6.6 \times 10^{6}$ daltons.

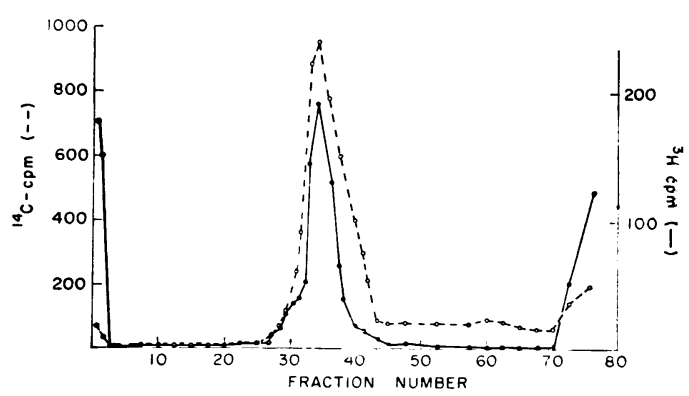

FIG. 7. Sedimentation of KRV-DNA and polyoma virus-DNA. The viruses were disrupted in $0.2 \mathrm{~N} \mathrm{NaOH}$ for 15 min at $23 \mathrm{C}$ added to the top of an $11-\mathrm{ml} 5$ to $30 \%$ sucrose gradient, $0.02 \mathrm{M}$ Tris $(\mathrm{pH}$ 12.2) and $1.0 \mathrm{M}$ $\mathrm{NaCl}$, and centrifuged at 35,000 rev/min for $18 \mathrm{hr}$ in a type $41 T$ rotor. Fractions were collected from the bottom of the tube. Sedimentation is from right to left. Symbols: O, ${ }^{14} \mathrm{C}-\mathrm{KR} V-\mathrm{DN} A ; \mathrm{O},{ }^{3} \mathrm{H}$-polyoma virus$D N A$. 


\section{DISCUSSION}

Some of the physical and chemical properties of KRV and its extracted DNA are reported here. $\mathrm{KRV}$ is similar in many of its characteristics to the small DNA-containing viruses, the minute virus of mice (MVM), and the bacteriophage $\phi X 174$. A comparison of some of the properties of these viruses is found in Table 3. The three virus particles are similar in size with diameters of 20 to $28 \mathrm{~nm}(6,19,28)$. Their buoyant densities are also very similar, although they were measured under different conditions. For MVM and $\phi \mathrm{X} 174$, the buoyant densities were determined by analytical equilibrium centrifugation in cesium chloride in a Spinco model $E$ ultracentrifuge. To determine an approximate buoyant density for infective $K R V$, isopycnic centrifugation of the virus in $\mathrm{CsCl}$ in a Spinco model $\mathrm{L}$ centrifuge was used. The density of the fractions containing the peak of HA activity and infectivity was then determined.

The sedimentation coefficient of KRV is reported here to be approximately 122 . The $S_{20}$, w was determined by zonal centrifugation of KRV with polyoma virus and SV40 viruses as markers. The sedimentation coefficients of KRV determined separately with each marker virus varied from each other by less than $3 \%$. This method of determination of $S_{20}$, wh the advantage of using a small amount of virus material, i.e., less than $0.02 \mu \mathrm{g}$. The distance sedimented in the gradient was shown by many workers to be almost exactly proportional to the sedimentation coefficient $(3,4)$. The cosedimentation of the virus marker of known $S_{20}$, w with the KRV of unknown $S_{20}$, w helps to eliminate any effects that convection,

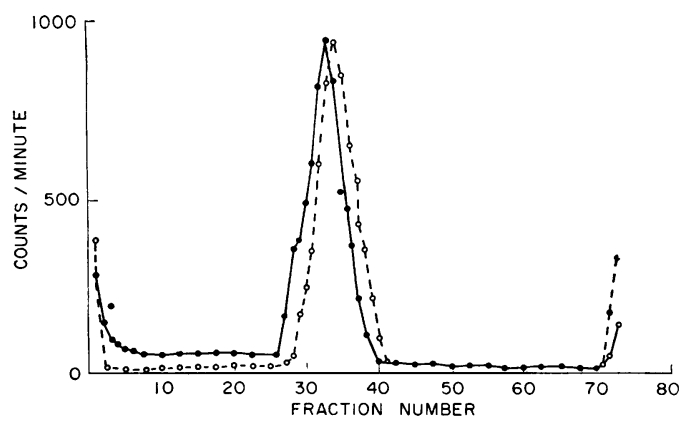

FIG. 8. Sedimentation of purified $K R V-D N A$ and polyoma virus-DNA component II. The DNA preparations were sedimented in a 5 to $30 \%$ sucrose gradient, $0.02 \mathrm{M}$ Tris, and $1.0 \mathrm{M} \mathrm{NaCl}(\mathrm{pH} \mathrm{12.2)}$ for $18 \mathrm{hr}$ at $35,000 \mathrm{rev} / \mathrm{min}$ in a type $S V 41 T$ rotor. Sedimentation is from right to left. Symbols;,${ }^{8} H-K R V-D N A$; $O,{ }^{14} \mathrm{C}$-polyoma virus-DNA component $I I$.
TABLE 2. Comparison of Kilham rat virus (KRV), $\phi X 174$, and minute mouse virus (MVM)

\begin{tabular}{l|c|c|c|c|c}
\hline \multicolumn{1}{|c|}{ Virus } & $\begin{array}{c}\text { Dia- } \\
\text { meter }\end{array}$ & $\begin{array}{c}\text { Buoyant } \\
\text { density } \\
\text { in CsCl }\end{array}$ & $\begin{array}{c}\text { Sedimen- } \\
\text { tation } \\
\text { coefficient }\end{array}$ & $\begin{array}{c}\text { Molecular } \\
\text { weight }\end{array}$ & $\begin{array}{c}\text { DNA } \\
\text { content }\end{array}$ \\
\cline { 2 - 3 } & $n m$ & $g / m l$ & $S_{20, w}$ & dallons & $\%$ \\
KRV & 20 & 1.41 & 122 & $6.6 \times 10^{6}$ & 25.6 \\
$\phi X 174$ & 22 & 1.43 & 114 & $6.2 \times 10^{6}$ & 25 \\
MVM & 28 & 1.41 & 110 & & \\
\hline
\end{tabular}

molecular weight, and concentration may have had on the sedimentation of the viruses. As a control, polyoma virus and SV40 virus were sedimented together under the same conditions. The

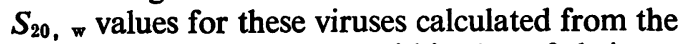
zonal centrifugation were within $5 \%$ of their reported $S_{20}$, w. values. The $S_{20}$, w values for $\phi \times 174$ and MVM were determined by band centrifugation in a Spinco model E ultracentrifuge. Some of the variation in the $S_{20}$, w values between KRV and the other two viruses may be due to the different method of determination of the value.

The percentage of DNA in KRV and $\phi \times 174$ were both determined chemically; they both contain approximately $25 \%$ DNA. The molecular weight of KRV was calculated from the determined molecular weight of its DNA and the percentage of DNA in the intact virion. It is very similar to the molecular weight of $\phi \mathrm{X} 174$ calculated in the same manner. The intact virions of KRV, MVM, and $\phi \mathrm{X} 174$ were all shown to react in a similar manner with formaldehyde. The increase in absorbancy at $260 \mathrm{~nm}$ with KRV as reported in the results section was 13 to $16 \%$. MVM is reported to show an increase in absorbancy at $260 \mathrm{~nm}$ of $18 \%$ (6) and $\phi X 174$ of $21 \%$ (25). Differences in secondary structure of these viral DNA species could account for some of the variation in their response to formaldehyde.

Other small DNA-containing viruses, the $\mathbf{H}$ viruses, and X14 also have similar properties. $\mathbf{H}_{1}$ sas a reported buoyant density in cesium chloride of 1.39 , and the virion contains $25 \%$ DNA ( $L$. Cheong, J. Fogh, and R. K. Barclay, Fed. Proc. 24: 596, 1965). $\mathrm{X} 14$ has a buoyant density in $\mathrm{CsCl}$ of 1.40 (21). All of these small DNA-containing viruses are probably closely related.

DNA was extracted from KRV and its base composition, density melting temperature profile, and reaction with formaldehyde were determined. All of these criteria indicated that the DNA was single-stranded in nature. MVM and $\phi \mathrm{X} 174$ were also reported to contain singlestranded DNA by using these same criteria $(25$, 
TABLE 3. Comparison of DNA extracted from Kilham rat virus (KRV), $\phi X 174$, and minute mouse virus (MVM)

\begin{tabular}{|c|c|c|c|c|c|c|}
\hline \multirow{2}{*}{ Virus } & \multicolumn{4}{|c|}{ Base composition $^{a}$} & \multirow{2}{*}{$\begin{array}{l}\text { Buoyant } \\
\text { density } \\
\text { in } \mathrm{CsCl}\end{array}$} & \multirow{2}{*}{$\begin{array}{c}\text { Molecular } \\
\text { weight }\end{array}$} \\
\hline & A & $\mathrm{T}$ & G & $\mathrm{C}$ & & \\
\hline & & & & & $g / m l$ & daltons \\
\hline KR V & 26.7 & 30.8 & 20.0 & 22.5 & 1.715 & $1.7 \times 10^{6}$ \\
\hline$\phi \times 174$ & 24.6 & 32.8 & 24.2 & 18.4 & 1.723 & $1.7 \times 10^{6}$ \\
\hline MVM & 26.7 & 32.8 & 19.3 & 21.2 & 1.722 & $1.7 \times 10^{6}$ \\
\hline
\end{tabular}

${ }^{a}$ Abbreviations: A, adenine, $T$, thymine, $G$, guanine, $C$, cytosine. Values indicate molar amounts of each nucleotide expressed as a percentage of the total nucleotide recovered.

a $-1=0$ 26). Some of the properties of the DNA from these three viruses are compared in Table 3 . The similarities in base composition are striking. All three single-stranded DNA species contain at least $30 \%$ thymine and approximately $25 \pm 2 \%$ adenine. More variation is found among the three species with respect to the guanine and cytosine content. The buoyant density in $\mathrm{CsCl}$ of the three DNA species determined in the Spinco model $E$ ultracentrifuge are very similar $(7,24)$. The slightly lower density found for KRV, if significant, may indicate more intrachain hydrogen bonding or other secondary structure differences in KRV-DNA as opposed to the DNA species from $\phi \mathrm{X} 174$ and MVM. The $S_{20, w}$ of KRV was determined by zonal centrifugation in an alkaline sucrose gradient by using polyoma DNA as a marker. This method of determining the sedimentation coefficient is discussed above. The molecular weight of the DNA was calculated from the $S_{20 \text {,w }}$ value by using the relationship of Studier for alkali denatured-single-stranded DNA (27). The molecular weight of $\phi \times 174$ and MVM were determined by different methods $(7,8)$. The three molecular weight values are identical (Table 3 ). The DNA of $\phi$ X174 was shown to be a circular molecule. The circularity or linearity of MVM and KRV has not been demonstrated.

The animal viruses KRV and MVM share many properties in both the intact virion and the extracted DNA with the bacteriophage $\phi \times 174$. There are differences between the three organisms, however, in regard to host specificity and antigenicity. $\phi \mathrm{X} 174$ grows in the bacterium Escherichia coli $\mathrm{C}$, a property not shared with the animal viruses. MVM can grow in rat cells and in mouse cells. KRV can grow in rat cells but not in mouse cells (6). Antiserum prepared against $\mathrm{KRV}$ and MVM is not cross-reactive, suggesting that the two viruses are antigenically distinct. MVM can also agglutinate mouse red blood cells, a property not shared by KRV (6). Further similarities and differences between the small DNA-containing viruses will be elucidated in the future.

\section{LITERATURE GITED}

1. Babcock, V. I., and C. M. Southam. 1967. Stable cell line of rat nephroma in tissue culture. Proc. Soc. Exp. Biol. Med. 124:217-219.

2. Baer, P. M., and L. Kilham. 1962. Rat virus and periodontal disease. Oral Surg. Oral Med. Oral Pathol. 15:756-763.

3. Brittin, R. J., and R. B. Roberts. 1960. High-resolution density gradient sedimentation analysis. Science 131:32-33.

4. Burgi, E., and A. D. Hershey. 1963. Sedimentation rate as a measure of molecular weight of DNA. Biophys. J. 3:309321.

5. Burton, K. 1956. A study of the conditions and mechanism of the diphenylamine reaction for the colorimetric estimation of deoxyribonucleic acid. Biochem. J. 62:315-323.

6. Crawford, L. V. 1966. A minute virus of mice. Virology 29:605-612.

7. Crawford, L. V., E. A. C. Follett, M. G. Burdon, and D. J. McGeoch. 1969. The DNA of a minute virus of mice. J. Gen. Virol. 4:37-46.

8. Fiers, W., and R. L. Sinsheimer. 1962. The structure of the DNA of bacteriophage $\phi \times 174$. III. Ultracentrifuge evidence for a ring structure. J. Mol. Biol. 5:424-434.

9. Jamison, R. M., and H. D. Mayor. 1965. Acridine orange staining of purified rat virus strain X14. J. Bacteriol. 90:1486-1488.

10. Josse, J., A. D. Kaiser, and A. Kornberg. 1961. Enzymatic synthesis of deoxyribonucleic acid. VIII. Frequencies of nearest neighbor base sequences in deoxyribonucleic acid. J. Biol. Chem. 236:864-875.

11. Kilham, L., and L. J. Olivier. 1959. A latent virus of rats isolated in tissue culture. Virology 7:428-437.

12. Kilham, L. 1966. Viruses of laboratory and wild rats. In Viruses of laboratory rodents. Nat. Cancer Inst. Monogr. 20:117-140.

13. Koch, M. A., H. J. Eggers, F. A. Anderer, H. D. Schlimberger, and H. Frank. 1967. Structure of simian virus 40. Virology 32:503-510.

14. Lowry, O. H., N. J. Rosebrough, A. L. Farr, and R. J. Randall. 1951. Protein measurement with the Folin phenol reagent. J. Biol. Chem. 193:265-275.

15. Mandel, M., C. Schildkraut, and J. Marmur. 1968. Use of $\mathrm{CsCl}$ density gradient analysis for determining the guanine plus cytosine content of DNA, p. 184-195. In L. Grossman and K. Moldave (ed.), Methods in enzymology 12, part B. Academic Press Inc., New York.

16. Margolis, G., L. Kilham, and P. R. Ruffolo. 1968. Rat virus disease, an experimental model of neonatal hepatitis. Exp. Mol. Pathol. 8:1-20.

17. Marmur, J., and P. Doty. 1962. Determination of the base composition of deoxyribonucleic acid from its thermal de naturation temperature. J. Mol. Biol. 5:109-118.

18. May, P., A. Niveleau, G. Berger, and C. Bralovsky. 1967. Recherches sur le DNA du virus $\mathbf{K}$ du rat. J. Mol. Biol. 27:603-614.

19. Mayor, H. D., and J. L. Melnick. 1966. Small deoxyribonucleic acid-containing viruses (picodnavirus group). Nature 210:331-332.

20. Patterson, M. S., and R. C. Greene. 1965. Measurement of low energy beta-emitters in aqueous solution by liquid scintillation counting of emulsions. Anal. Chem. 37:854-857.

21. Payne, F. E., T. F. Beals, and R. E. Preston. 1964. Morphology of a small DNA virus. Virology 23:109-113.

22. Rabson, A. S., L. Kilham, and R. L. Kirschstein. 1961. Intranuclear inclusions in Rattus (Mastomys) natalensis injected with rat virus. J. Nat. Cancer Inst. 27:1217-1223. 
23. Robinson, D. M., and F. M. Hetrick. 1969. Single-stranded DNA from the Kilham rat virus. J. Gen. Virol. 4:269-283.

24. Shilkraut, C. L., J. Marmur, and P. Doty. 1962. Determination of the base composition of deoxyribonucleic acid from its buoyant density in CsCl. J. Mol. Biol. 4:430-443.

25. Sinsheimer, R. L. 1959. Purification and properties of bacteriophage $\phi$ X174. J. Mol. Biol. 1:37-42.

26. Sinsheimer, R. L. 1959. A single stranded deoxyribonucleic acid from bacteriophage $\phi X 174$. J. Mol. Biol. 1:43-53.
27. Studier, F. W. 1965. Sedimentation studies on the size and shape of DNA. J. Mol. Biol. 11:373-390.

28. Tromans, W. S., and R. W. Horne. 1961. The structure of bacteriophage $\phi \times 174$. Virology 15:1-7.

29. Vinograd, J., J. Lebowitz, R. Radloff, R. Watson, and $\mathbf{P}$. Larpis. 1965. The twisted circular form of polyoma viral DNA. Proc. Nat. Acad. Sci. U.S.A. 53:1104-1111.

30. Winocour, E. 1963. Purification of polyoma virus. Virology 19:158-168. 